\title{
UNSPOKEN ALTERNATIVES TO EXPENSIVE HOUSING
}

How to deliver affordable housing without inflating landlord profits

Most housing subsidies end up increasing landlord and developer profits rather than reducing housing costs for

$\underset{\text { australia }>}{4}$

TheAustralialnstitute

Research that matters. residents.

Public land rent schemes that provide discounted land access to owners, and private Community Land Trusts, are proven ways to ensure that subsidies reduce costs for homeowners.

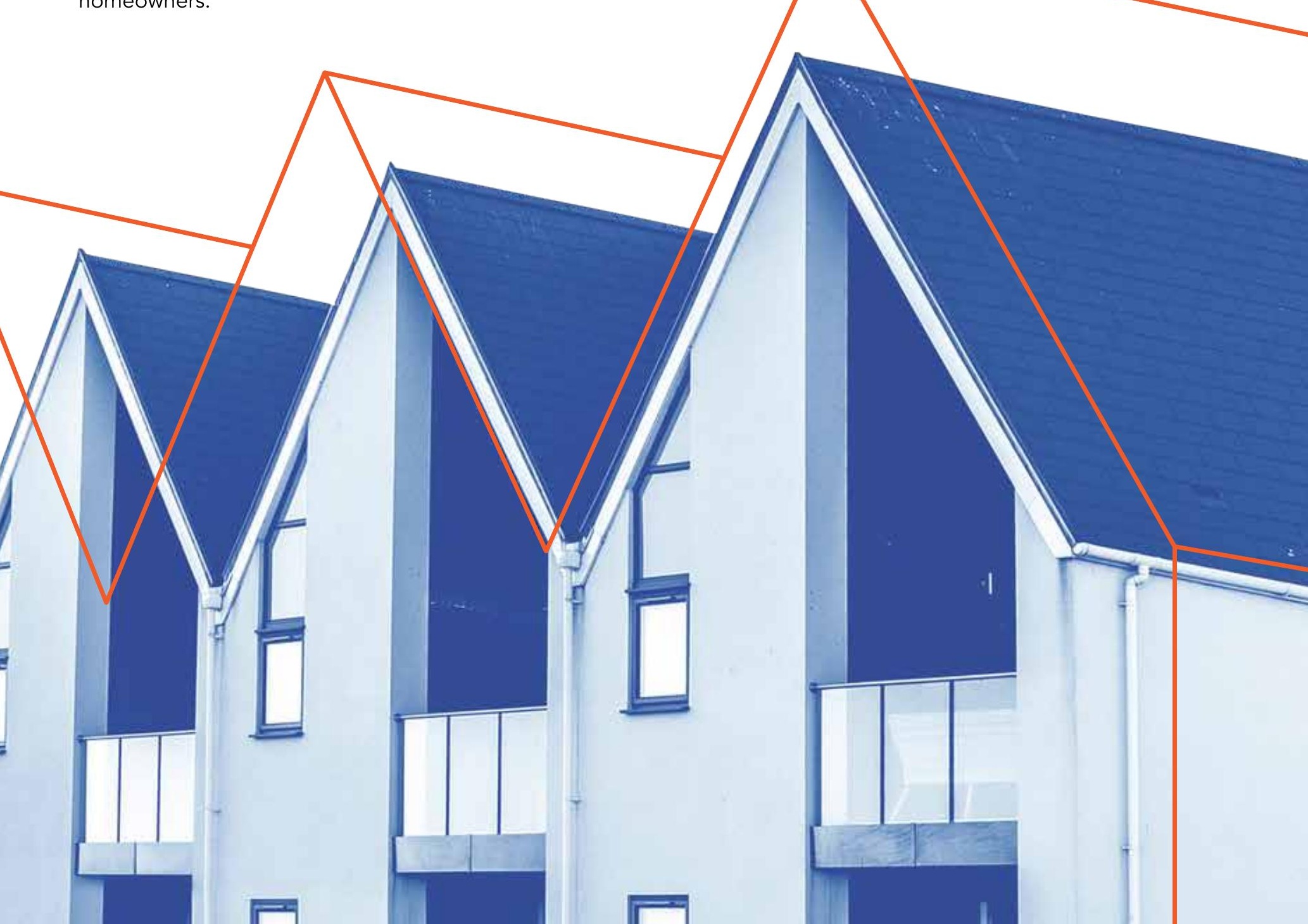




\section{ABOUT THE AUSTRALIA INSTITUTE}

The Australia Institute is an independent public policy think tank based in Canberra. It is funded by donations from philanthropic trusts and individuals and commissioned research. We barrack for ideas, not political parties or candidates. Since its launch in 1994, the Institute has carried out highly influential research on a broad range of economic, social and environmental issues.

\section{OUR PHILOSOPHY}

As we begin the 21st century, new dilemmas confront our society and our planet. Unprecedented levels of consumption co-exist with extreme poverty. Through new technology we are more connected than we have ever been, yet civic engagement is declining. Environmental neglect continues despite heightened ecological awareness. A better balance is urgently needed.

The Australia Institute's directors, staff and supporters represent a broad range of views and priorities. What unites us is a belief that through a combination of research and creativity we can promote new solutions and ways of thinking.

\section{OUR PURPOSE - 'RESEARCH THAT MATTERS'}

The Institute publishes research that contributes to a more just, sustainable and peaceful society. Our goal is to gather, interpret and communicate evidence in order to both diagnose the problems we face and propose new solutions to tackle them.

The Institute is wholly independent and not affiliated with any other organisation. Donations to its Research Fund are tax deductible for the donor. Anyone wishing to donate can do so via the website at https://www.tai.org.au or by calling the Institute on 026130 0530. Our secure and user-friendly website allows donors to make either one-off or regular monthly donations and we encourage everyone who can to donate in this way as it assists our research in the most significant manner.

Address: Level 1, Endeavour House, 1 Franklin St

Canberra, ACT 2601

Tel: $\quad$ (02) 61300530

E-mail: mail@tai.org.au

Website: www.tai.org.au

ISSN: $\quad 1836-9014$

\section{ABOUT PROSPER}

Prosper Australia is an independent, not-for-profit organisation campaigning for economic justice. Prosper's mission is educate policy makers and the general public in the economics of locational advantage. We advocate for the taxation of the economic rents arising from property rights in land and natural resources, as well as natural and government created monopolies.

Prosper is widely recognised for its role in highlighting the affordability pressures that vacant land and housing imposes on affordability. This year Prosper is celebrating its' 127th Annual Henry George Commemorative Dinner.

Website: www.prosper.org.au

Donate: www.prosper.org.au/pari

\section{ABOUT THE AUTHOR}

Cameron Murray is economist specialising in property and urban development, environmental economics, rentseeking and corruption. He is a coauthor of the book Game of Mates: How favours bleed the nation, a Senior Economist at The Australia Institute, and a lecturer at the University of Queensland.

Website: gameofmates.com

Blog: fresheconomicthinking.com

Twitter: @DrCameronMurray 


\section{Summary}

- Secure, affordable housing is a worthy policy objective.

- Unfortunately, many affordable housing policies are ineffective because they allow monopolist landholders to capture the value of subsidies for themselves.

- If Australian governments want to enact policies to make housing cheaper for residents, they should focus on housing options that provide residents access to housing without having to pay the monopoly market price.

- Option 1: The ACT's Land Rent Scheme (LRS) is a publicly-run housing system that ensures residents get a discount on the market price of land, while providing secure long-term tenure, just as with private ownership.

- Over 3,200 households in the ACT have taken advantage of the scheme, saving \$69 million on housing costs since its inception in 2008. The remaining LRS residents currently save $\$ 9$ million per year on housing.

- An LRS owner can save 37\% of their housing costs over ten years compared to renting.

- Land rent revenue to the ACT government was $\$ 9.2$ million in 2017, although the net financial effect is closer to revenue neutral due to forgone land sales.

- State governments, councils, or even the federal government, could start their own land rent schemes at no financial cost by either acting as a land developer or by purchasing new housing from the private market.

- Option 2: Community Land Trusts (CLTs) are a privately-run housing scheme that provide secure long-term housing at below market prices. The CLT is an incorporated entity, much like a land body corporate', that inserts a layer of control over property ownership for land and dwellings within the trust.

- CLTs are designed to pass on any subsidy received (from government, council, or philanthropy) to residents by regulating sales at below-market prices, while removing the right of residents to set their sale price.

- CLTs can reduce the cost of housing compared to the market price by more than $25 \%$. For example, over its 25 years of operation the Champlain CLT (Burlington, Vermont) offered housing 26\% below market prices on average.

- A CLT owner can save 52\% of their housing costs over ten years compared to renting.

- Many CLTs have operated in the United States for decades, offering secure housing below-market price, saving residents billions in housing costs.

- Governments can easily facilitate the expansion of a CLT industry at no cost by redirecting housing subsidies that currently go to existing landholders towards supplying land for CLTs.

- Establishing land rent schemes or CLTs should be a priority over privatisation of government land for monopoly-priced housing development. 


\section{Table of Contents}

$\begin{array}{ll}\text { Summary } & 03\end{array}$

Unspoken housing alternatives $\quad 05$

$\begin{array}{ll}\text { Monopoly land markets are the problem } & 08\end{array}$

Landholders get housing subsidies when they can set market prices $\quad 10$

The ACT Land Rent Scheme 12

Property rights-LRS vs private markets $\quad 15$

Financial costs to residents $\quad 16$

$\begin{array}{ll}\text { Core economic lever of LRS } & 18\end{array}$

Limitations of the Land Rent Scheme $\quad 19$

Community Land Trusts $\quad 20$

Property rights-CLT vs private markets $\quad 22$

Financial cost to residents $\quad 23$

Resale price control $\quad 25$

Core economic lever of CLTs $\quad 26$

Non-market rationing for CLT rights $\quad 27$

Limitations of CLTs $\quad 27$

So, what? $\quad 28$

How to get more housing without the land monopoly? 29

$\begin{array}{ll}\text { Policy ideas } & 30\end{array}$ 


\section{UNSPOKEN HOUSING ALTERNATIVES}

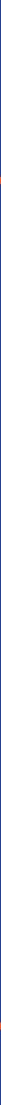


The current housing debate in Australia has narrowed dramatically to the point where the only politically palatable option is to avoid affordable housing policy. The de facto policy is to rely on private rental and ownership as the only housing options in the country.

One current approach is to provide tax breaks to developers to facilitate a build-to-rent model, rather than the typical build-to-sell arrangements. ${ }^{1}$ What makes this approach quite strange is that there are already 1.8 million landlords in Australia (or around $20 \%$ of households). ${ }^{2}$ Under the build-buy-rent model, such investors enjoy generous tax concessions, like the 50\% capital gains tax discount and negative gearing losses against labour incomes. Providing more tax breaks for another set of landlords, this time landlords who are also developers, further entrenches the narrow scope of options to simply more tax-advantaged marketpriced private housing. It seems far removed from a policy designed to engineer secure low-cost housing. Unfortunately, relying on private property markets to deliver affordable housing is like relying on the fox to watch the hens. Private property markets that provide access to land and housing through competitive pricing are the problem, not the solution, when it comes to providing cheaper housing options. Land markets are a monopoly, with landholders able to withhold land for the maximum price that comes from buyer competition. The market price of land is the monopoly price.

It is merely "busy work" for a policy community to debate housing policy while wearing the self-imposed straightjacket that does not allow public sector participation or non-monopoly priced housing options to be genuinely considered (see Box 1 for more).

Instead of pandering to the 'make markets work' crowd, it is time to talk about unspoken alternatives for affordable, secure housing that overcome the problem of land monopoly. One such alternative is the Land Rent Scheme (LRS), currently operating in the Australian Capital Territory (ACT). This scheme rents land at around half the market rate to qualifying residents, allowing them to access the security benefits of homeownership without paying the market-price for land.

1 Cranston, M. (2017). Build to rent a key for Australian housing affordability. Australian Financial Review. 30 Aug 2017. https://www.afr.com/real-estate/build-to-rent-a-key-for-australian-housing-affordability-20170830-gy6y2x, and Davies, A. (2017). Build-to-rent plan could put Australian residential property sector back on the boil. The Guardian. 18 Nov 2017. https://www.theguardian.com/australia-news/2017/nov/18/build-to-rent-plan-could-put-australian-residential-property-sector-back-on-the-boil 


\section{BOX 1: AUSTRALIA'S HOUSING DEBATE IS NOT ABOUT CHEAPER HOUSING BUT ABOUT BUSY WORK}

In 2015 two researchers from the University of Sidney, Nicole Gurran and Peter Phibbs, published a paper entitled "Are Governments Really interested in Fixing the Housing Problem? Policy Capture and Busy Work in Australia" in the Housing Studies journal. Their answer was no.

In just the past fifteen years an array of major reports and inquiries have been conducted into housing in Australia. All the while, market priced access to housing has become more expensive than ever, and non-market priced housing options fewer than ever.

Reports and inquiries include, for example:

- Menzies Research Centre: 2003 Prime Ministerial Taskforce on Home Ownership

- Productivity Commission's 2004 First Home Ownership Report

- The 2007 implementation of Queensland's Housing Affordability Strategy

- A Good House is Hard to Find Report from the 2008 Senate Select Committee on Housing Affordability in Australia

- Western Australia’s Affordable Housing Strategy 2010-2020

- COAG Reform Council: Housing Supply and Affordability Reform 2012

- The 2015 New South of Wales Parliamentary Inquiry into Social, public and affordable housing

- National Housing Supply Council (NHSC): State of Supply Reports (2008, 2010, 2011, 2012 - 2013)

- Senate Inquiry into Affordable Housing, 2014-2015

- 2016 Parliamentary Inquiry into Home Ownership

- 2017 Parliamentary Legal and Social Issues Committee Inquiry into the Public Housing Renewal Program

- $\quad$ AHURI - Inquiry into social impact investment for housing and homelessness outcomes, 2018

- $\quad$ AHURI - Inquiry into increasing affordable housing supply, 2018.

Another unspoken alternative is to direct subsidies towards privately-run Community Land Trusts (CLT), which are private legal vehicles for providing secure homeownership to residents at below-market prices in perpetuity.

To help broaden the housing policy debate, this report first explains the core economic problem of monopoly power in land markets which has undermined many policies, particularly subsidies, intended to reduce the price of housing. ${ }^{3}$ The monopoly power of landholders has meant that most subsidies given to residents for housing end up as gains for existing landholders.

Then, the two so-far unspoken publicly- and privately-run alternatives are investigated. In particular, they are analysed with respect to how they overcome the land monopoly problem. Lastly, some simple policies to facilitate more of these non-market housing options are discussed. 


\title{
Monopoly land markets are the problem
}

\author{
Rent, in short, is the price of monopoly, arising \\ from the reduction to individual ownership of \\ natural elements which human exertion can neither \\ produce nor increase. - George (1879) ${ }^{4}$
}

When widely-accepted economic theory about land markets is wrong, it means that policy advice derived from it is misguided. Classical economists understood for two centuries that the market price of land, both to lease short-term or own in perpetuity, is the result of landholders holding monopoly power. Any land price charged is an economic rent. Briefly, economic rent is a payment to a property owner above the cost of production (plus small positive return). Since land is a type of property (or capital in the economic jargon) that is costless to create, all income flowing to landholders is a form of economic rent. That little vacant piece of land in your town's central district has risen in value over time from nearly nothing decades ago, to millions today, but has required no additional input costs from the landholder. Hence its price is an economic rent.

The same is true of a house that has been unchanged for two decades, but where the rent has tripled. Since the building is identical, or perhaps in worse condition, the gains are economic rents to the landholder that come without any additional input costs.

Modern economics has unfortunately downplayed, if not entirely ignored, this fact. Getting the economics of land right is crucial to understanding how alternative non-monopoly-priced forms of land access can make housing cheaper.

To get the economics right, a critical distinction must be made between land, a monopoly property right, and buildings, objects without such rights but which can 'attach' to the rights of the land they are built on. It might be easier to think about this distinction by imagining that all buildings are caravans that can be removed and replaced at will. In this case, the nation's land is a caravan park and a monopoly supplier of land locations that have value regardless of which caravan is parked on which location.

While it is possible to compete in the supply of building new caravans, competing in the supply of new land locations at the caravan park is not possible. Even if each plot of land in the caravan park is owned by a different person, their individual and joint incentive is not to undercut each other on price. This is possible because they are insulated from potential new competitors. The only way a new land supplier can enter the market is to buy land off an existing owner, which is in effect not new supply at all. Even if that does occur, the new owner would have the same incentive to withhold their land for the highest price as the previous owner had. In economic terms, there is no free entry to the land market, and hence no threat of competition. ${ }^{5}$

In sum, property rights in land are a monopoly. ${ }^{6}$ Because of this, landholders, who as a group own the fixed resource of locations, are able to hold off supplying their land to market to ensure those who need land for housing pay the maximum price. Landholder rights are only an option, not an obligation, to develop, rent or sell, and hence the market price of land is the monopoly price.

4 George, H. (1879). Progress and poverty: An enquiry into the cause of industrial depressions, and of increase of want with increase of wealth. The Remedy. K. Paul, Trench \& Company.

5 This is abundantly clear when you look at the phenomena of land-banking. In Australia, the top eight property developers had over 272,000 residential lots in development. Rather than outcompete each other by supplying as much as possible at lower prices, they planned to supply them over a 15-year period, making sure to maximise the present value of the cash flows from all their lots, and in the process, not competing on price. Collyer, D. (2014). Englobo. Prosper Australia. https://www.prosper.org.au/2014/10/31/land-banking-profits-during-a-housing-supply-crisisenglobo-2014

Additionally, in markets that lack free entry, repeated pricing games have been shown to result in convergence to the monopoly price regardless of the number of competitors. Huck, S. et. al. (2003). Zero-knowledge cooperation in dilemma games. Journal of Theoretical Biology, 220(1), 47-54, and Huck, S. et. al. (2004). Through trial and error to collusion. International Economic Review, 45(1), 205-224.

6 Posner, E. A., \& Weyl, E. G. (2017). Property Is Only Another Name for Monopoly. Journal of Legal Analysis, 9(1), 51-123.

https://academic.oup.com/jla/article-pdf/9/1/51/17648497/lax001.pdf 
For the past quarter of a century in Australia this has resulted in renting households spending $20 \%$ of their gross (before-tax) income on rentals, ${ }^{7}$ which has varied by just $+/-1 \%$ and seems to be a natural constraint on the willingness to spend on renting. The market-price of buying a home reflects this market-priced rent, along with expectations of growth.

This monopoly price of housing flows through to the economic rent of land in the same way that the accommodation cost of a caravan at a caravan park flows through to the site rent- the land rent is the accommodation cost minus the cost of the caravan.

Under certain conditions the joint power of landholders to withhold their land from the market for the monopoly price can be undermined. If there is an external force compelling landholders to sell, like the home foreclosures in the United States following the 2008 financial crisis, the monopoly power to withhold can be temporarily weakened. Even in this case, however, many mortgagees in possession exercised their market power and refused to sell to stop market prices falling further. ${ }^{8}$

Because of this monopoly power, the provision of housing subsidies to landholders will not change their incentive to withhold for the monopoly price. Indeed, many existing subsidies intended to make housing more affordable-directed either at buyers, renters, or developers-do not change the incentive to charge market prices by landholders. Hence, landholders, who are on the 'short' side of the property market, capture all these subsidies as economic rents.

Because of this monopoly power of landholders, people who need to pay market prices for land will always find that housing is relatively expensive, particularly for lower income households who must bid against higher income households for more attractive locations. Households in the bottom fifth of the income distribution had to spend $28 \%$ of their income on housing in 2017-18, up from $22 \%$ in 1994-95. However, households in the top fifth of the distribution maintained their $10 \%$ ratio. ${ }^{9}$ Higher inequality makes it much more difficult for lower income households to compete for market-priced housing.

Indeed, one of the great benefits of home ownership is that it insulates households from the monopoly pricing power of landholders. Home renters must compete up the market price each year when leases are renewed. Home owners only face the market price of land once as a lump sum. After that, home owners are no longer exposed to any increase in the market price for land, and indeed become landholders themselves, capturing future gains in monopoly prices in the form of land price increases (capital gains). The ability to leverage against these gains is a further advantage. 


\section{Landholders get housing subsidies when they can set market prices}

The monopoly power of landholders undermines many well-intentioned housing subsidies which simply end up in the hands of landholders without making access to land and housing cheaper for new buyers and renters.

\section{TAX BREAKS TO LANDHOLDERS... GO TO LANDHOLDERS}

In the build-to-rent story, corporate landholders argue that they require tax breaks in order to build and own housing to supply to the rental market. In doing so, this supply is expected to bring down rents and prices. But the reality of the land monopoly says otherwise.

No property developer is going to build so much housing that it brings down the market price of rents and homes, undermining their own profitability. Even some property developers, like Harry Triguboff, have called out this story as nonsense, and an excuse by some of the largest developers to get an extra financial gift in the form of tax discounts. ${ }^{10}$ This policy was well-received by both sides of politics, though support for such tax breaks from the Liberal National Party (LNP) has been recently withdrawn. ${ }^{11}$

\section{FIRST HOME OWNER'S GRANT (FHOG) GOES TO LANDHOLDERS}

One of the housing subsidies intended to reduce the cost of housing in private markets for a subset of buyers is the FHOG, which is a cash payment to first-time home buyers. Since this type of subsidy increases the budget of potential buyers who bid against each other to buy homes, it gets passed on to landholders in the form of higher market prices. ${ }^{12}$ The Productivity Commission (PC $)^{13}$, amongst others, ${ }^{14}$ have noted this effect, yet the policy remains politically popular.

\section{STAMP DUTY DISCOUNTS GO TO LANDHOLDERS}

Stamp duty is a government charge on property buyers. Unfortunately, discounts on stamp duty go to the seller, not the buyer. ${ }^{15}$ Consider buyers with a strict budget limit for their home purchase. If some costs are reduced it allows them to reallocate their budget to bid up the home price against other buyers who also face lower costs in their housing budget. Even the Urban Development Institute of Australia (UDIA) has noted the following:

\section{FHB stamp duty exemptions and concessions will direct demand towards product of limited or constrained supply based on price points, thereby increasing prices in already heavily demanded locations. ${ }^{16}$}

In an attempt to make home-buying cheaper, this policy increases the market price for landholders. Despite this, the policy of stamp duty discounts for housing affordability remains politically popular. ${ }^{17}$

\footnotetext{
10 Bleby, M. (2018). Harry Triguboff pours cold water on build-to-rent tax break push. Australian Financial Review. 5 June 2018. https://www.afr.com/real-estate/harry-triguboff-pours-cold-water-on-buildtorent-tax-break-push-20180604-h10yoy

11 Greber, J. (2017). Scott Morrison slams property sector for wanting unfair build-to-rent tax breaks. Australian Financial Review. 17 Sept 2017. https://www.afr.com/news/economy/morrison-slams-property-sector-for-wanting-unfair-buildtorent-tax-breaks-20170917-gyj3qa

12 A similar economic outcome happens from other first home buyer subsidies, like the 'rates holiday' initiated by Strathbogie Shire Council in Victoria. Shire of Strathbogie. (2018). Rates holiday for first home buyers. https://www.strathbogie.vic.gov.au/development/economic-development/rates-holiday 


\section{REZONING GAINS GO TO LANDHOLDERS}

Another form of subsidy intended to reduce the market price of housing comes from rezoning land for higher value residential uses without charging the market value for those new development rights. Since there is no obligation on landholders who receive rezoning rights to supply more dwellings at a rate sufficient to depress the market prices, nor supply dwellings below market rates, they bank this subsidy as increased land values. ${ }^{18}$ In the ACT the value of these rezoning decisions to landholders is taxed by the government at $75 \%$ of their market value, raising $\$ 21$ million in 2016-17. ${ }^{19}$

\section{DISCOUNTED DEVELOPER CHARGES GO TO LANDHOLDERS}

In most states, development of housing requires a payment to the council or state government to help cover the cost of infrastructure upgrades. This payment is usually called a developer charge. To encourage the construction of new dwellings at a lower cost, many governments have discounted these charges. Yet, because landholders are monopolists, reducing their development costs does not reduce the prices they are able to charge. Instead of reducing prices, discounted developer charges are economic rents that go straight to the bottom line of developer profits. ${ }^{20}$

\section{SUBSIDISED RENTS CAN GO TO LANDHOLDERS}

For subsidies to make housing cheaper for residents they must be accompanied with restrictions on the landholder's ability to charge market prices. Australia's National Rental Affordability Scheme (NRAS) does just that, requiring landholders in the scheme to rent at $20 \%$ below market prices for ten years to qualify for a subsidy.

Unfortunately, because developers must voluntarily join the scheme, the value of the subsidy must exceed the value of the $20 \%$ discount. Because of this, many NRAS-approved dwellings are sold to investors above market prices, reflecting the value of this extra incentive to join the scheme. Indeed, there are also opportunities to exaggerate the counterfactual market rent to which the $20 \%$ discount is applied, shifting more of the subsidy to landholders rather than residents. ${ }^{21}$

In sum, trying to 'make markets work' in a monopoly land market is a dead-end if your goal is to reduce the price of land and therefore the housing attached to it. The economic logic of land markets suggests that making housing cheaper requires alternatives that help residents avoid the monopoly pricing power of landholders. 
$-$

THE ACT LAND RENT SCHEME

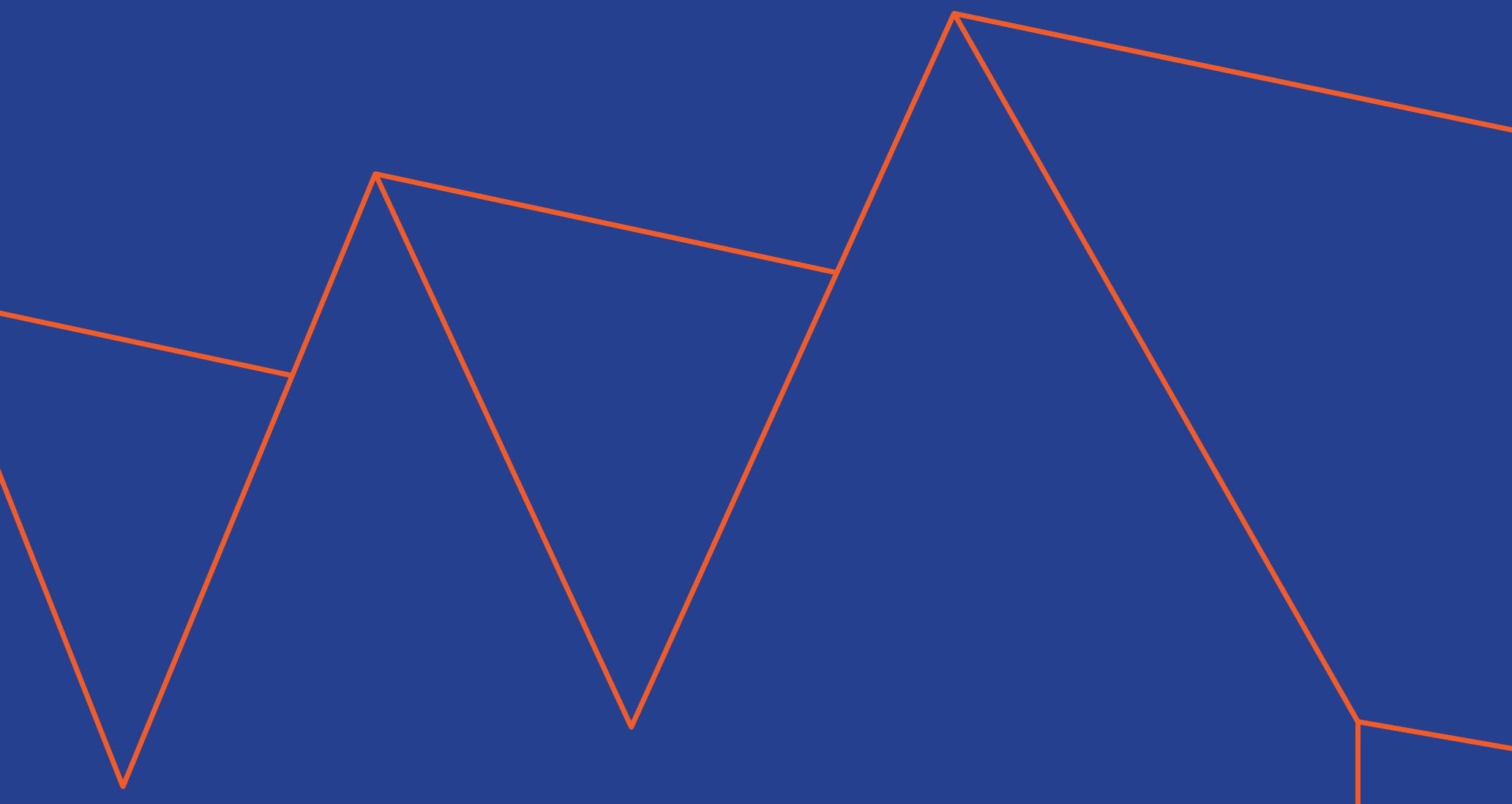


The ACT land rent scheme (LRS) provides homeowners a way to access land at a below-market price. ${ }^{22}$ Rather than homeowners paying upfront for a perpetual right to land at market prices, the ACT government provides a perpetual land lease to residents at an annual rental price of $2 \%$ of the land value. Compared with buying the land with a mortgage paying $5.2 \%$ interest per year (the current average), this approximates a $60 \%$ discount on the land cost.

The LRS was motivated by political concerns about rising house prices during the early 2000s price boom, coming into effect in July 2008. ${ }^{23}$ Between 2008 and September 2013, the scheme allowed any household to access a land rent scheme at a $4 \%$ land rent rate (mortgage interest rates at the time where around $8 \%$ ), with only households with a total gross income below $\$ 95,900$ qualifying for a more discounted $2 \%$ land rent rate. In October 2013 the scheme was updated to be a single 2\% rate only (mortgage interest rates had by then dropped to around 5\%). This was available to qualifying households with an income below $\$ 160,001 .{ }^{24}$ Only newly released vacant land from the Suburban Land Agency is available for the LRS, and residents are required to construct a house on the land within two years of the lease being granted. Land is revalued each year, and the land rent applies at $2 \%$ of the new value. Note though that the rate at which the assessed value can increase for LRS land is capped at the local wage index. This further insulates LRS resident from monopoly prices during land price booms.

The key economic advantage of this scheme is that it provides access to land through a mechanism which avoids the monopoly pricing power of landholders, reducing the cost of housing to residents. Up until June 2017, 3,268 households had entered the scheme (see Table 1), with an average market-price of land at $\$ 275,000$, and a total market-value of land of $\$ 960$ million. From 2012 to 2017 the LRS applied to $14 \%$ of new housing land lots in the ACT.

\section{TABLE 1: SUMMARY STATISTICS OF ACT LRS SINCE INCEPTION}

\begin{tabular}{|l|r|r|r|r|}
\hline Year & Lots contracted & \multicolumn{2}{r}{ Lots settled } & \multicolumn{2}{r|}{ Average lot price } & $\begin{array}{r}\text { Lots converted } \\
\text { out of LRS }\end{array}$ \\
\hline $2008-09$ & 122 & 0 & $\$ 250,500$ & 0 \\
\hline $2009-10$ & 342 & 0 & $\$ 233,075$ & 0 \\
\hline $2010-11$ & 874 & 232 & $\$ 240,159$ & 51 \\
\hline $2011-12$ & 573 & 605 & $\$ 266,064$ & 29 \\
\hline $2012-13$ & 242 & 730 & $\$ 282,652$ & 11 \\
\hline $2013-14$ & - & 289 & $\$ 363,959$ & 521 \\
\hline $2014-15$ & - & 787 & $\$ 361,939$ & 759 \\
\hline $2015-16$ & - & 308 & $\$ 239,961$ & 209 \\
\hline $2016-17$ & - & 317 & $\$ 237,661$ & 477 \\
\hline
\end{tabular}

Sources: Land Development Agency annual reports and via email from the Office of the Chief Minister. Dashed cells are unknown or unavailable data.

While the number of remaining lots in the LRS is not certain (the relevant government agencies have been unable to confirm this number) a good estimate can be made of the cost savings of households in the LRS by extrapolating from the available data.

At the end of FY2017 there were 1,211 households remaining in the LRS. Of these, around $73 \%$ are at the $2 \%$ land rent rate, and the remainder at the old $4 \%$ rate. With a prevailing $5.2 \%$ mortgage interest rate, and an average lot price of $\$ 275,000$, the annual housing cost savings in 2018 for LRS residents, compared to the interest payments from borrowing to purchase the land at monopoly prices, is estimated to be $\$ 9$ million.

22 Suburban Land Agency. (2018). Land Rent Scheme. https://suburbanland.act.gov.au/en/land-rent-scheme, and ACT Revenue Office. (2018). Land rent scheme. https://www.revenue.act.gov.au/home-buyer-assistance/land-rent

23 ACT Government. (2007). Report of the Affordable Housing Steering Group. https://www.planning.act.gov.au/ data/assets/pdf file/0004/139900/140422report affordable housing steering group.pdf

24 As interest rates had fallen to near the previous LRS 4\% rate there was little advantage from renting land from the ACT government, rather than renting the money to buy the land from a bank and also getting any capital gain in land value. The new $2 \%$ rate represents a similar 3 percentage point discount to prevailing interest rates as the $4 \%$ land rent rate in 2008 . 
Doing the same calculation each year since its inception, based on the prevailing interest rates and share of residents in the $4 \%$ and $2 \%$ schemes, the LRS is estimated to have saved residents a total of $\$ 69$ million in housing costs. ${ }^{25}$ That $\$ 69$ million is money that would have accrued to monopolist landlords. Instead, this saving has flowed to residents, who are far more likely to spend rather than save. This means that the funds circulate via consumer spending in the ACT economy, improving both the material well-being of households in the scheme and ACT businesses.

A 2012 survey of the scheme showed that $43 \%$ of LRS residents entered the scheme from the rental market, while $29 \%$ where owner-occupiers with a mortgage. ${ }^{26}$ This indicates that the LRS has allowed households to escape the rental market while insulating them from the monopoly land price, providing substantial housing cost savings.

What is perhaps surprising is that this survey also showed that most respondents planned to take up the option to purchase their land outright within the next 10 years. ${ }^{27}$ Indeed, the data in Table 1 confirms that between 2013 and 2015 more than 1,200 residents left the scheme. Some of this was because they were in the old $4 \%$ land rent, and interest rates were falling rapidly in this period, making it cost-effective to borrow money to buy rather than pay the $4 \%$ land rent. It may also be that the previous savings in housing costs had been saved, allowing residents to pay market prices to purchase their home.

But it also might partly be due to a particular rule in the LRS stating that when the household income of a resident in the scheme exceeds the qualifying income threshold, they must exit the scheme within two years

...by purchasing the land outright from the Government or by transferring the lease to another eligible applicant who meets the eligibility criteria for the discounted land rent. ${ }^{28}$

This creates a perverse incentive for households to keep their income below the threshold to retain their home. There is no clear economic reason why this rule should exist, and indeed, no reason why there should be a qualifying income in the first place.

The many LRS residents who have left the scheme appear to have devoted much of their cost savings from being in the scheme to buying housing at market prices in the future. This behaviour indicates a desire buy into the potential capital gains available from ownership. Yet this outcome means that fewer dwellings remain in the LRS long term and will not be available at a discounted price to future residents. It also means that the longevity of the scheme rests on having the ACT's Suburban Land Agency continue to offer new land lots under the LRS.

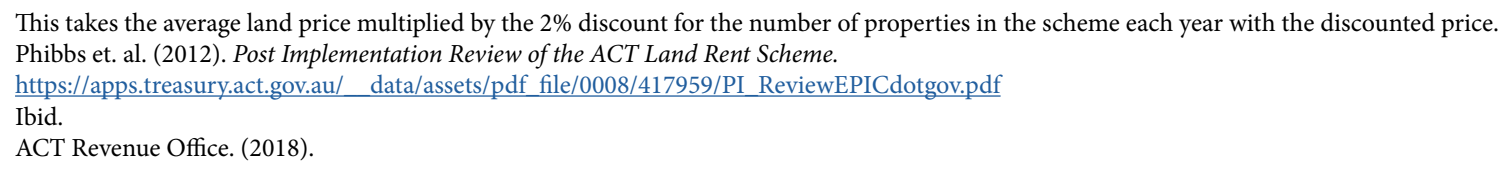




\section{Property rights-LRS vs private markets}

The core change in property rights for LRS-owners is that the LRS removes the right to of landholders to capture the monopoly price of land upon sale, since the government retains ownership of the land, with residents holding a perpetual lease requiring an annual rental payment at a discounted rate. Residents are also unable to sublet the property at market prices.

Table 2 compares the property rights of LRS-owners to private ownership and rental markets. Notice that the key rights involved with secure land access in private property ownership are preserved-the right is perpetual and able to be inherited or passed on to family members.

\section{TABLE 2: COMPARISON OF PROPERTY RIGHTS BUNDLES FOR LRS}

\begin{tabular}{|c|c|c|c|c|}
\hline & Property right & $\begin{array}{l}\text { Private } \\
\text { rental }\end{array}$ & $\begin{array}{l}\text { LRS } \\
\text { ownership }\end{array}$ & $\begin{array}{l}\text { Private } \\
\text { purchase }\end{array}$ \\
\hline \multirow{2}{*}{$\begin{array}{l}\text { Rights related to } \\
\text { residency }\end{array}$} & Period of right & $\begin{array}{l}\text { Annual } \\
\text { or less }\end{array}$ & Perpetual & Perpetual \\
\hline & Right to inherit & No & Yes & Yes \\
\hline \multirow{2}{*}{$\begin{array}{l}\text { Rights related to } \\
\text { transferral }\end{array}$} & Right to sell & No & Yes & Yes \\
\hline & Right to sublet & No & No & Yes \\
\hline \multirow{2}{*}{$\begin{array}{l}\text { Rights related to } \\
\text { market pricing }\end{array}$} & Right to set sale price & No & No & Yes \\
\hline & Right to set sublet price & No & No & Yes \\
\hline
\end{tabular}

Shaded rights are those where the LRS retains control.

When it comes to transferring the property rights of LRS residents, the LRS scheme retains control, allowing only transfers to new participants in the LRS. New buyers pay the seller an amount they think reflects the value of taking over the land rent on this LRS home compared to their alternative of building a home on a new vacant LRS block. LRS residents also retain the option to buy the land for the assessed market value at any time.

This control of sales ensures that properties that enter the LRS remain in a pool of properties available below market prices to qualifying households or are otherwise taken out of the pool by residents who have benefitted from the scheme but have later opted to purchase the land. Compared to the rights of private tenants, the residents in the LRS scheme have a much more secure bundle, but not so generous as the rights under private ownership. 


\section{Financial costs to residents}

To demonstrate how the scheme affects the housing costs for residents a simple scenario is shown in Table 3. This scenario compares the costs to residents under the LRS to rental and purchase at market prices for a home with a $\$ 250,000$ construction cost on a plot of land with a market-price of $\$ 275,000$, and market weekly rental rate of $\$ 450$ for the home.

\section{TABLE 3: EXAMPLE FINANCIAL COSTS TO RESIDENTS}

\begin{tabular}{|c|c|c|c|}
\hline & Private rental & LRS & Private purchase \\
\hline Total purchase price & \$450/week & $\$ 250,000$ & $\$ 525,000$ \\
\hline Deposit & $\$ 1,800$ & $\$ 50,000$ & $\$ 104,000$ \\
\hline Interest (year one) & - & $\$ 10,400$ & $\$ 21,840$ \\
\hline Principal repayment (year one) & - & $\$ 4,076$ & $\$ 8,560$ \\
\hline Land rent & - & $\$ 5,500$ & $\$ 0$ \\
\hline Annual total & $\$ 23,400$ & $\$ 19,976$ & $\$ 30,400$ \\
\hline Cost share of income & $28 \%$ & $24 \%$ & $36 \%$ \\
\hline LRS cost reduction & - & $34 \%$ & - \\
\hline Finance period & $1 \mathrm{yr}$ & $25 \mathrm{yrs}+$ & $25 \mathrm{yrs}$ \\
\hline Length of tenure & 1 year & Perpetual & Perpetual \\
\hline Deposit saving period & 7 weeks & $5 y r s$ & $10 \mathrm{yrs}$ \\
\hline Annual cost growth & $2 \%$ & $1 \%$ & 0 \\
\hline
\end{tabular}

Scenario is $\$ 275,000$ land price and $\$ 250,000$ dwelling construction cost. Deposit is $20 \%$ total upfront cost of $\$ 250,000$ for the LRS and $\$ 525,000$ for private purchase. The loan amount is $80 \%$ of the value, with interest at $5.2 \%$, for a period is 25 years. Principal repayment is the amount in the first year. The annual total cost for private purchase stays the same in the absence of interest rate changes, though the LRS cost increases with land values. The length of finance for the LRS is 25 years for the dwelling mortgage, but perpetual for the land rent. The current average interest rate on Australian mortgages is $5.2 \%{ }^{29}$ Cost share of income is for household income of $\$ 85,000$.

Notice that the annual costs of the LRS are lower than for renting, and also increase at a lower rate, since only the land rent share of their total costs increases at market rates, and these increases are capped to increases in the local wage index.

Over time, the cost profile for each type of resident in the scenario from Table 3 looks quite different. In Figure 1, costs for each of the three resident types over time are shown. LRS homes are cheaper than private purchases initially because rather than a mortgage payment at a $5.2 \%$ interest rate on the land price, there is only a $2 \%$ rent payable. However, unlike a private purchase, the costs rise over time as the land value increases. At the end of the mortgage period, the costs of private ownership go to zero, while the LRS resident continues to pay a land rent. 


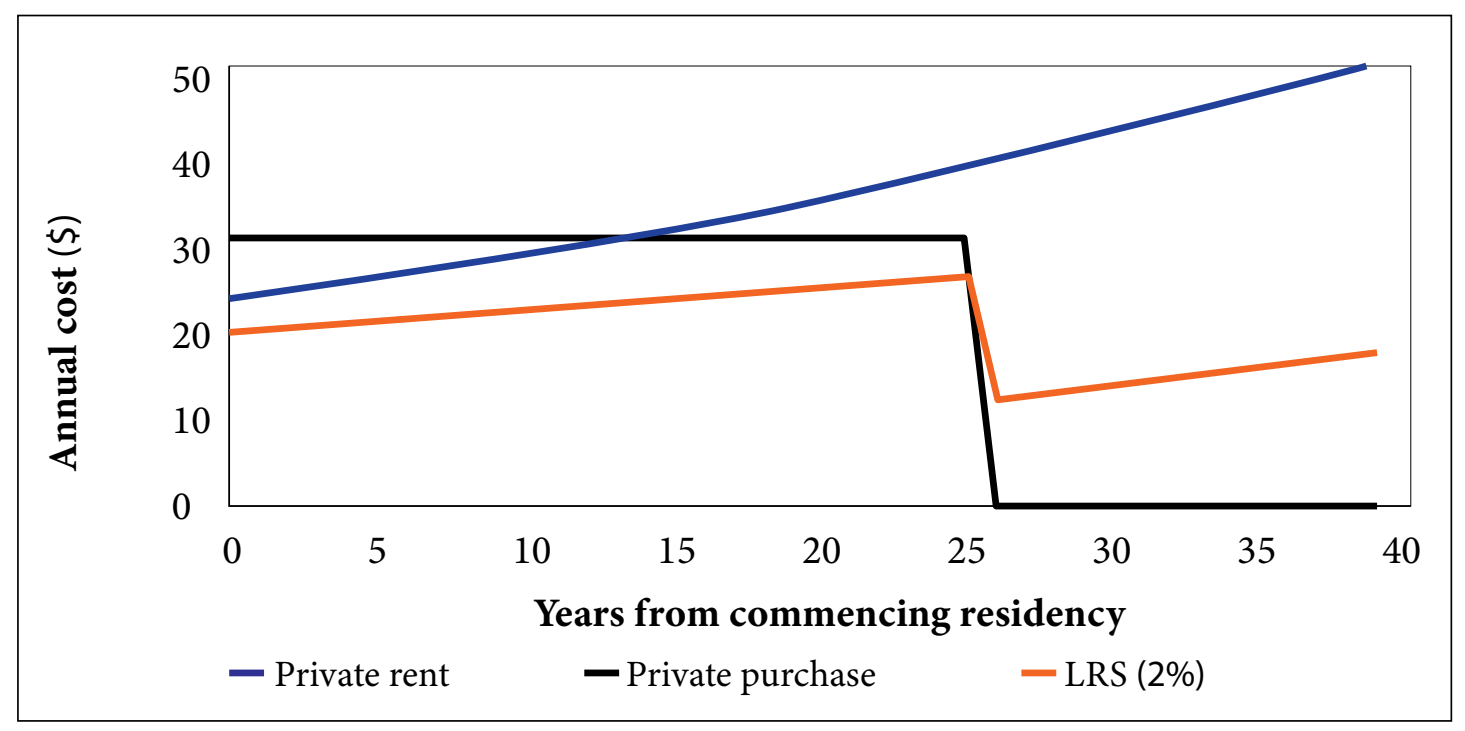

\section{FIGURE 1: TIME PROFILE OF RESIDENCY COSTS}

Compared to renting in the private market, the LRS is much more attractive at all points in time. Not only is it cheaper in terms of ongoing costs, but the resident actually buys the dwelling (the building), which has a value when they leave the scheme if maintained in good condition. ${ }^{30}$ Even if the LRS resident borrows $100 \%$ of the home construction cost, rather than the $80 \%$ assumed here, the LRS scheme becomes cheaper than renting in 6 years. As mentioned earlier, most LRS residents were renters prior to entering the scheme.

The cost of LRS ownership over ten years in this example is $\$ 207,800$, while for renting it is $\$ 256,200$, meaning the LRS scheme can help renters save $\$ 48,400$ on the cost of housing over ten years. At the same time, these LRS owners are accumulating equity in their home, equivalent to some $\$ 45,300$ after ten years. The total benefit of being an LRS owner compared to renting is $\$ 93,700$ over ten years, or about $37 \%$ of the market rental paid. 


\section{Core economic Lever of LRS}

The main economic lever that allows the LRS to provide below-market land is the control over the land rental rate, which could just as easily be a fixed annual payment, a share of household income, or an even lower rate of market value. The difference between the land rental rate charged (as a percent of market land value) and the cost of borrowing for the ACT government, is a subsidy. However, this subsidy is not a complete 'free lunch' from the government to LRS owners. Land ownership is retained by the government which accumulates the rising value of these land assets on its balance sheet, which at the end of FY2017 were worth $\$ 375$ million. ${ }^{31}$ As well, the government earns land rent as revenue, which was $\$ 9.2$ million in FY2017. ${ }^{32}$ The net effect is that there is no net economic cost to the government for providing this belowmarket-priced housing option.

To demonstrate how this subsidy occurs, Table 4 compares the situation where the government sells land at the market price, and the situation where it instead keeps the land in the LRS but borrows the market value of the land (which it would otherwise sell) in bond markets to retain the same income. In both of these situations the government has the same $\$ 275,000$ income at the time of the land sale. However, in the LRS case the ownership of the LRS land comes with the ongoing benefit of a $2 \%$ land rent payment, while the borrowing comes with a $3 \%$ annual cost. If the value of the LRS land increases by $1 \%$ or more, the net effect is that there is no economic cost to the government from this scheme as the LRS rent and capital gains income exceeds the cost of borrowing in bond markets.

\section{TABLE 4: COMPARISON OF GOVERNMENT FINANCIAL POSITION}

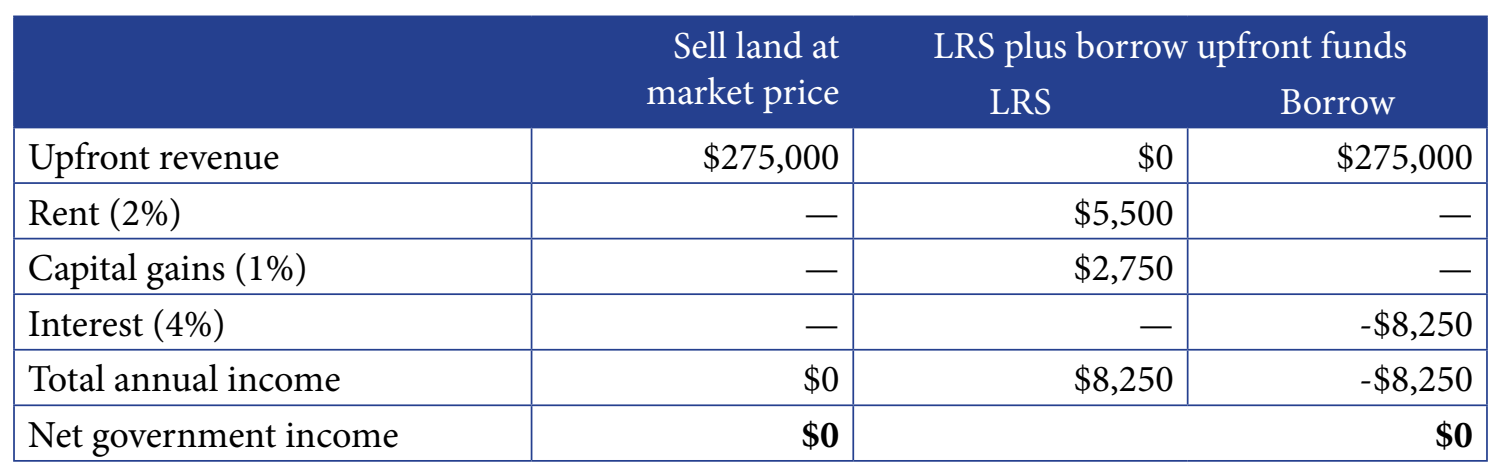

This does, however, sound like a free lunch. How can the cost to the government be zero but there also be positive benefits for LRS residents?

The answer is that capital gains on land are merely transferred to the government from the LRS resident. The housing costs of LRS residents are lower because they are not buying the right to capital gains (future increases in the market price). Instead, the government retains this right, which allows it to offer land at far below the market-price with little, to no, economic cost. 


\section{Limitations of the Land Rent Scheme}

The economic lever that allows the LRS to provide cheap housing with no economic cost to the government is also one of the limitations of the system, according to some. For example, online forums discussing potential LRS purchases commonly contain comments like the following:

...you own the depreciating asset, the government owns the appreciating asset... ${ }^{33}$

This is not strictly true. The house certainly depreciates in accounting terms, but in economic terms will retain its replacement cost as a value if it is well-maintained for many decades. LRS residents who sell at a future point in time to new LRS residents will be able to charge them the replacement cost of the house at that point in time, as their alternative is to buy a vacant piece of land and build a similar home at a price that reflects future construction costs. ${ }^{34}$

Certainly, the effect of interest rates and speculation on land prices create gains for private landholders, but not LRS residents. However, LRS residents pay a much lower cost of homeownership to forgo these potential financial benefits.

The other limitation, as discussed earlier, is the income limit for remaining qualified for the LRS creates an incentive for households not to increase their income so as to maintain lower housing costs. Removing this limit would easily solve this without any economic cost.

As residents voluntarily buy their LRS home outright, it reduces the pool of LRS homes potentially available for future residents. In the ACT this is not a significant problem, as the government can supply more new land into the scheme at any time through its Suburban Land Agency. Other states could also create similar agencies to develop land for such schemes on an ongoing basis to ensure a large pool of available below-market-priced land.

Lastly, financing for home construction can still be a problem for some potential LRS residents. None of the four biggest banks offer loans for home construction to residents in the scheme, though there are now many small banks involved.

It is not clear why the ACT government could not itself offer construction loans to LRS residents. A loan for construction of an LRS dwelling from the Police Bank has a $4.5 \%$ interest rate. ${ }^{35}$ The ACT government can borrow by issuing bonds at around a 3\% rate and simply provide these funds as a construction loan to LRS residents. 
$-$

COMMUNITY

LAND TRUSTS

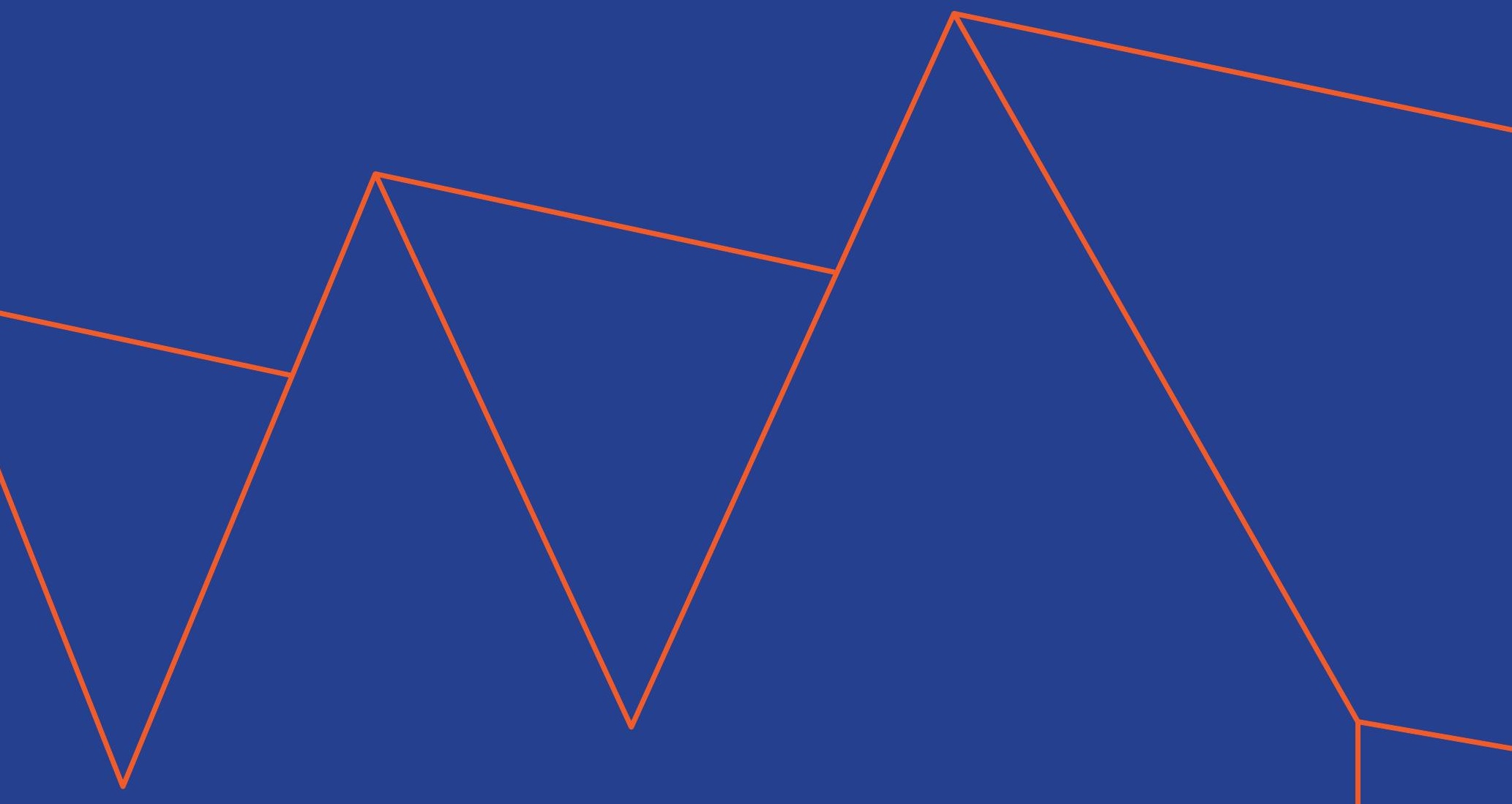


A CLT is a perpetual private incorporated body that manages access to land it owns in non-market ways to ensure that current and future residents have secure housing at affordable, below-market prices. Much like a 'land body corporate,', a CLT maintains a layer of control over property within the trust. This ensures that any subsidy provided to it is passed on to residents, current and future.

Unlike a land rent scheme, a CLT does not require ongoing payments to access land. Instead it offers a purchase price to residents that is below the monopoly land price, but with the condition that any sale must be at a CLT-determined discounted price in the future.

This resale price control is the primary difference between land in a CLT and standard private land rights, with the CLT retaining control over the price at which sublets can occur. It is this control that ensures that below-monopoly price housing can be achieved. Without this control, a CLT would be subject to the failures of other housing subsidies, which end up in the hands of landholders rather than residents.

To create a CLT that is able to provide housing below-market price, an initial subsidy is needed. The form of subsidy that a CLT could use to provide below-market priced land can be varied. For example it could:

- be given public land at little or no cost by local or state governments,

- purchase an agricultural or industrial site and be rezoned for higher density residential uses,

- acquire part of a larger site for free as a condition on development for a large land developer,

- acquire a site, or existing apartment building, at open market value with philanthropic funding, or

- be a community organisation that already owns a site for development.

This initial subsidy gets passed on to CLT residents through regulated below-market sale and rental prices with a formula for determining these prices locked in when the CLT is established. The CLT Board approves sales and rents to qualifying buyers or renters. On the board are typically owners and tenants of the CLT, as well as representatives from local governments or other interested parties (such as representative of philanthropic funds that put forward the initial subsidy). For more details on the legal arrangements available for CLTs in Australia, see Crabtree et. al. (2013). ${ }^{36}$

In economic terms the CLT can be best thought of as being a type of caravan park- an entity in control of access to land but which does not own the buildings. These are supplied by CLT landholders. However, instead of renting the land at market prices for short stays, a CLT offers perpetual access to the land with the right to build a permanent dwelling(s). Residents purchase access to land below market prices and bring their own dwelling to attach to the land. When a resident sells their right to land, with their own dwelling now attached, the CLT determines a set price the seller can receive that reimburses them for their dwelling and sometimes adds a little on top for a share of land value gains. The method of resale price control is usually set when the CLT is established via an agreed 'resale formula'.

Though there are relatively few CLTs globally, with just 250 in the United States, ${ }^{37}$ they have grown in popularity in recent decades as an alternative housing option in a climate of extremely high land prices. In the UK the number of CLTs has grown from two to 280 since the 2008 financial crisis. ${ }^{38}$

The successful early CLTs have now lasted many decades. One of the original CLTs in the United States got its start with subsidy support from then Burlington Mayor Bernie Sanders. ${ }^{39}$ The Champlain Housing Trust in Burlington Vermont began in 1984 and has since accumulated over 2,200 dwellings. ${ }^{40} \mathrm{~A}$ recent study showed that new residents in this CLT get secure long-term housing at a $26 \%$ discount to the market price on average. ${ }^{41}$ The 233 new residents in the study saved around $\$ 8$ million in upfront housing costs compared to purchasing similar properties elsewhere. In San Francisco, the Citywide Inclusionary Affordable Housing Program has run since 1992 and now has a portfolio of over 800 properties. A study of the last 50 sales from this CLT showed that the typical buyer got a $47 \%$ discount on the market price of the home, saving them nearly $\$ 12$ million in housing costs. ${ }^{42}$

36 Crabtree, L. et. al. (2013). The Australian community land trust manual.

https://researchdirect.westernsydney.edu.au/islandora/object/uws:26922/datastream/PDF/view

37 Hatcher,D. (2016). Community land trust model: Opportunities and challenges of preserving affordable housing. Profitwise, (2), 18-23. https://www.chicagofed.org\%2F \%2Fmedia\%2Fpublications\%2Fprofitwise-news-and-views\%2F2016\%2Fpnv-issue2-2016-landtrust-article3-pdf.pdf London CLT. (2018). About Us. http://www.londonclt.org/about-us/

39 Blumgart, J. (2016). How Bernie Sanders Made Burlington Affordable. Slate. 19 Jan 2016. http://www.slate.com/articles/business/metropolis/2016/01/bernie_sanders_made_burlington_s_land_trust_possible_it_s_still_an_innovative.html Champlain Housing Trust. (2018). About Us. https://www.getahome.org/about-us

41 Temkin, K. et. al. (2010). Shared Equity Homeownership Evaluation: Case Study of Champlain Housing Trust. The Urban Institute. p3. http://cltnetwork.org/wp-content/uploads/2014/01/2010-Case-Study-of-CHT.pdf

42 Temkin, K. et. al. (2010). Shared Equity Homeownership Evaluation: Case Study of the San Francisco Citywide Inclusionary Affordable Housing Program. The Urban Institute. p6. https://www.urban.org/sites/default/files/publication/29266/412239-Shared-Equity-Homeownership-Evaluation-Case-Studyof-the-San-Francisco-Citywide-Inclusionary-Affordable-Housing-Program.PDF 


\section{Property rights-CLT vs private markets}

To understand how CLTs can deliver housing below market prices, the remainder of this section provides an overview of the key economic features of CLTs, as well as some examples of how the housing costs of CLTs compare to private rental or ownership.

The core change in property rights for CLT-owners is that the CLT removes the right of landholders to set their own sale price. Allowing residents to sell their rights at market prices would simply give the same result as other housing subsidies that go to monopoly landholders - residents could buy into the CLT at discounted prices and immediately sell at monopoly prices, taking the subsidy for themselves.

Table 5 compares the property rights of CLT-owners to those in private ownership and rental markets. Like the LRS scheme, the key rights involved with secure land access in private property ownership are preserved.

But when it comes to rights involved with sales and pricing, the CLT exercises control, as the shaded cells in Table 5 denote. While CLT residents have the right to sell their CLT land, or to sublet it, when desired, these are approved by the CLT Board conditional on occurring at below-market prices, and often to low-income households that meet specific qualifying criteria set by the CLT. In many ways, these controls mirror some that occur in low-income public housing rented at below-market rates.

However, right to occupy in perpetuity combined with the ability to recover the value of any investment in dwelling improvements in the resale price means that incentives to maintain the home are the same as for those of private homeowners. The rights and incentives of CLT ownership are in that respect similar to private ownership.

TABLE 5: COMPARISON OF PROPERTY RIGHTS BUNDLES FOR CLT

\begin{tabular}{|c|c|c|c|c|}
\hline & Property right & $\begin{array}{l}\text { Private } \\
\text { rental }\end{array}$ & $\begin{array}{l}\text { CLT } \\
\text { ownership }\end{array}$ & $\begin{array}{l}\text { Private } \\
\text { purchase }\end{array}$ \\
\hline \multirow{2}{*}{$\begin{array}{l}\text { Rights related to } \\
\text { residency }\end{array}$} & Period of right & Annual & Perpetual & Perpetual \\
\hline & Right to inherit & No & Yes & Yes \\
\hline \multirow{2}{*}{$\begin{array}{l}\text { Rights related to } \\
\text { transferral }\end{array}$} & Right to sell & No & Yes & Yes \\
\hline & Right to sublet & No & Yes & Yes \\
\hline \multirow{2}{*}{$\begin{array}{l}\text { Rights related to } \\
\text { market pricing }\end{array}$} & Right to set sale price & No & No & Yes \\
\hline & Right to set sublet price & No & No & Yes \\
\hline
\end{tabular}

Shaded rights are those where the CLT will exercises control, requiring approval for subletting and sale in order to ensure it is done at below-market prices.

While the CLT resident's rights are certainly less than what private landholders get, these reduced rights are what helps to ensure that land access is both secure and affordable, and not associated with marketpriced monopoly land rents. Like the LRS, CLTs offer a bundle of rights that sit between private rental and private ownership. 


\section{Financial cost to residents}

Getting a set of perpetual property rights to land at below market prices means that residents in CLTs face far lower housing costs, both upfront, and in the future. Like other homeowners, once CLT-residents pay off the cost of their home they face no further costs.

The best way to compare the underlying financial differences between private ownership and CLT ownership is with a simple example. Table 6 provides a comparison of the cost profile for renting, CLT purchase, and private purchase for the same scenario used earlier in the LRS analysis.

There are two CLT scenarios used here to demonstrate the range of possible outcomes, since CLTs have many options for how they set the regulated below-market price of land. In the first scenario land is provided for free $(0 \%$ of the market price), while in the second the land is provided at $50 \%$ of the market price.

TABLE 6: EXAMPLE FINANCIAL COSTS TO RESIDENTS

\begin{tabular}{|c|c|c|c|c|}
\hline & $\begin{array}{r}\text { Private } \\
\text { rental }\end{array}$ & $\begin{array}{l}\text { CLT- land at } 0 \% \\
\text { market price }\end{array}$ & $\begin{array}{r}\text { CLT- land at } 50 \% \\
\text { market price }\end{array}$ & $\begin{array}{r}\text { Private } \\
\text { purchase }\end{array}$ \\
\hline Total purchase price & $\$ 450 /$ week & $\$ 250,000$ & $\$ 387,500$ & $\$ 525,000$ \\
\hline Deposit & $\$ 1,800$ & $\$ 50,000$ & $\$ 77,500$ & $\$ 104,000$ \\
\hline Interest & NA & $\$ 10,400$ & $\$ 16,120$ & $\$ 21,840$ \\
\hline Principal repayment & NA & $\$ 4,227$ & $\$ 6,318$ & $\$ 8,560$ \\
\hline Annual total & $\$ 23,400$ & $\$ 14,476$ & $\$ 22,438$ & $\$ 30,400$ \\
\hline Cost share of income & $28 \%$ & $17 \%$ & $26 \%$ & $36 \%$ \\
\hline CLT cost reduction & & $52 \%$ & $26 \%$ & \\
\hline Finance period & $1 \mathrm{yr}$ & $25 \mathrm{yrs}$ & $25 \mathrm{yrs}$ & $25 \mathrm{yrs}$ \\
\hline Length of tenure & 1 year & Perpetual & Perpetual & Perpetual \\
\hline Deposit saving period & 7 weeks & $5 y r s$ & $7.5 \mathrm{yrs}$ & $10 \mathrm{yrs}$ \\
\hline Annual cost growth & $2 \%$ & 0 & 0 & 0 \\
\hline
\end{tabular}

Scenario is $\$ 275,000$ land price and $\$ 250,000$ dwelling construction cost. Deposit is $20 \%$ total upfront cost of $\$ 250,000$ for the LRS and $\$ 525,000$ for private purchase. The loan amount is $80 \%$ of the value, with interest at $5.2 \%$, for a period is 25 years. Principal repayment is the amount in the first year. The annual total cost for private purchase and CLT purchase stay the same in the absence of interest rate changes. The length of finance for the LRS is 25 years for the dwelling mortgage, but perpetual for the land rent. The current average interest rate on Australian mortgages is $5.2 \%{ }^{43}$ Cost share of income is for household income of $\$ 85,000$.

The first important comparison is between private purchase and the CLT with land priced at $50 \%$ of the market price. Here, the annual cost of a mortgage to purchase the CLT is $26 \%$ lower than in private markets, at $\$ 22,438$ per year, instead of $\$ 30,040$ per year, over a 25 -year period (a nominal $\$ 190,050$ less). The lower the price that the CLT charges for its land, the higher the savings for residents, with the limit at a zero price for land. At this limit, the CLT in this scenario reduces the cost of buying this home by more than half, while also halving the time needed to save for a deposit.

Of note also is the time-profile of the costs of each of these options. CLT ownership, like private ownership, is a perpetual right. Meaning that after any mortgage cost is repaid there are no further housing costs for residents above maintenance, and for a CLT, a small administration cost (much like a body corporate fee for apartment owners, but typically much smaller). 


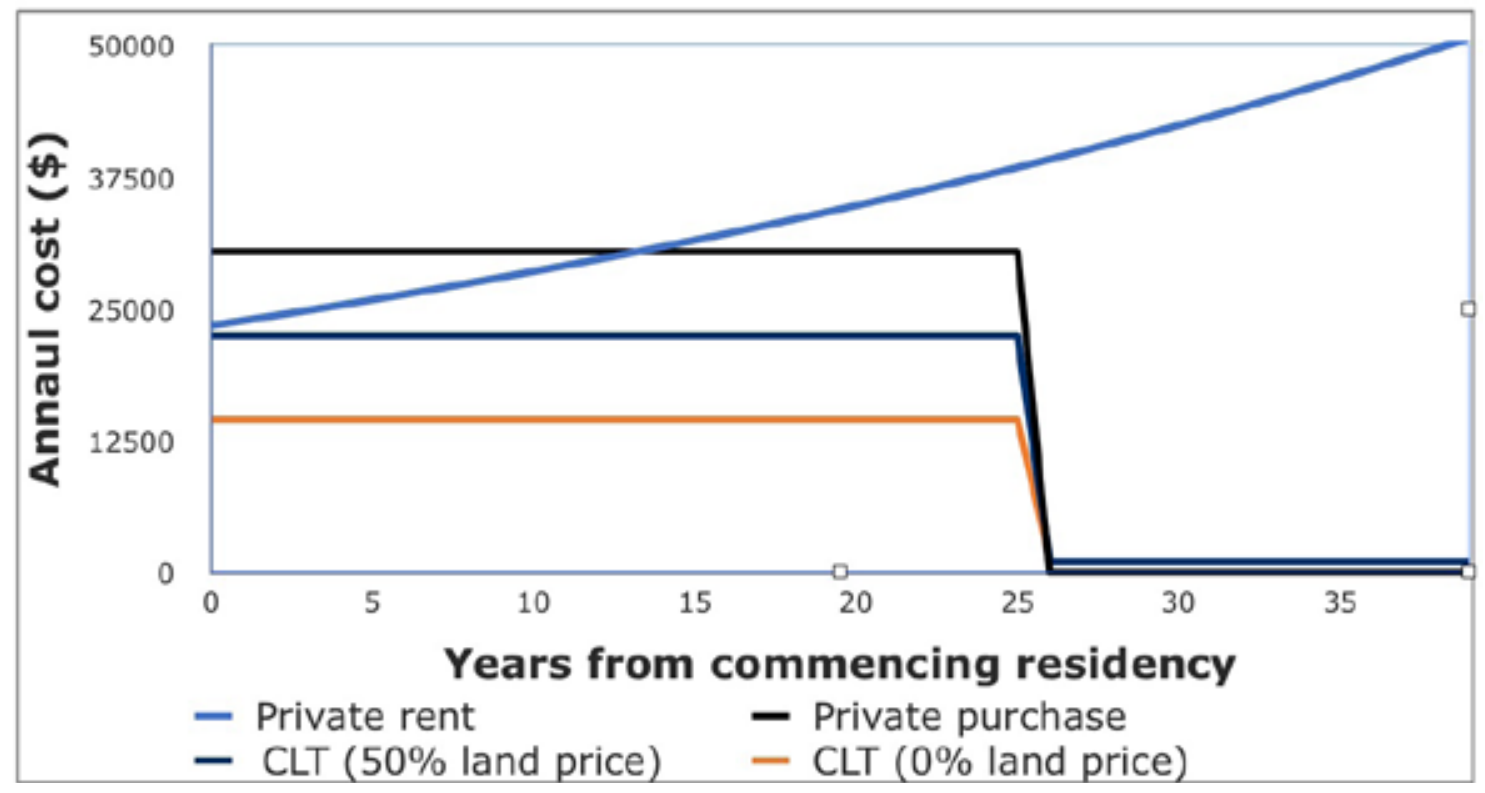

\section{FIGURE 2: TIME PROFILE OF RESIDENCY COSTS}

Figure 2 shows the profile of housing costs over time for scenarios in Table 6. An important point here is that the repeated exposure to market pricing for the renting household over time means that although their costs can be quite low to start, they are not able to escape market-pricing in the future. The vertical gap between the blue rental line and the CLT cost lines is the difference in cost between renting and the CLT. While a CLT can be a little more expensive than renting initially (even with the subsidised land price) as rents grow over time the costs of CLT ownership are much lower in the long-term, particularly when the mortgage is repaid. By reducing the costs of ownership, a CLT can help residents insulate themselves from monopoly-pricing of land, particularly as they near retirement age, offering benefits similar to homeownership in private markets.

In this example, the cost of CLT ownership at a $50 \%$ land price discount over ten years is $\$ 224,400$, compared to the cost of renting at $\$ 256,200$, for a total saving of $\$ 31,800$. However, over that time the household would have also accumulated $\$ 70,200$ in equity in the home that they could recover upon sale. In addition, they get a $50 \%$ share of the land price growth over the period, which at $2 \%$ per year is $\$ 30,100$. The total ten-year benefit compared to renting is $\$ 132,100$, or about $52 \%$ of the total market rental paid over the period. 


\section{Resale}

\section{price control}

The key economic lever that CLTs use to keep housing affordable to new residents is the resale price formula' - it determines the below-market price that dwellings can be sold for, while ensuring that the costs incurred by residents to construct their dwellings is recovered for them. This formula is set when the CLT is created in order to make housing for initial residents affordable. It also allows prospective buyers to know the CLT-regulated price they will receive if they decide to sell. This ensures that future buyers can buy into the CLT at below market-prices in the future.

There are two main approaches to setting a resale formula. The first is to apply a discount on the market price of the land component. An example of such a resale formula might be a $50 \%$ discount on the market price of the land component of the property. CLT homeowners who buy at this discounted price must also accept a sale price that is a $50 \%$ discount on the future market price of land.

This approach is common in CLTs. The Champlain Housing Trust, for example, applies a resale formula that lets residents get $25 \%$ of the capital gains multiplied by the discount on market price they originally received. ${ }^{44}$ The Northern California Land Trust applies a 70\% discount to appreciation in market price in their resale formula. ${ }^{45}$

The second approach is to apply an index-based formula that links the sale price to some desirable affordability metric, like median neighbourhood wages. For example, the formula may set a maximum price that reflects repayments of a 25 -year mortgage (at $80 \%$ of the price) being $25 \%$ of the suburb's median income. The council-run CLT, the Citywide Inclusionary Affordable Housing Program (San Francisco) applies a formula based on a median income buyer paying 33\% of their income on housing. ${ }^{46}$

Either way, the resale formula is what ensures that upfront subsidies are not captured by landholders, but instead go to current and future residents.

To demonstrate how each of these types of formula would apply, Table 7 continues the scenario from Table 6 of the $50 \%$ discount on the market price of land. It adds a scenario with an index-based resale formula that applies a criteria that the sale price must be set at a point where a mortgage on $80 \%$ of the sale price can be repaid in 25 years at $25 \%$ of the suburb median income. In this case, the two resale formulas provide resale prices after ten years within $9 \%$ of each other. However in reality, the price cycle of land might mean during boom periods the resale formula applying a discount on market price could be much higher than the index-based formula.

\section{TABLE 7: TYPES OF RESALE FORMULA FOR LAND (INCLUDING HOME)}

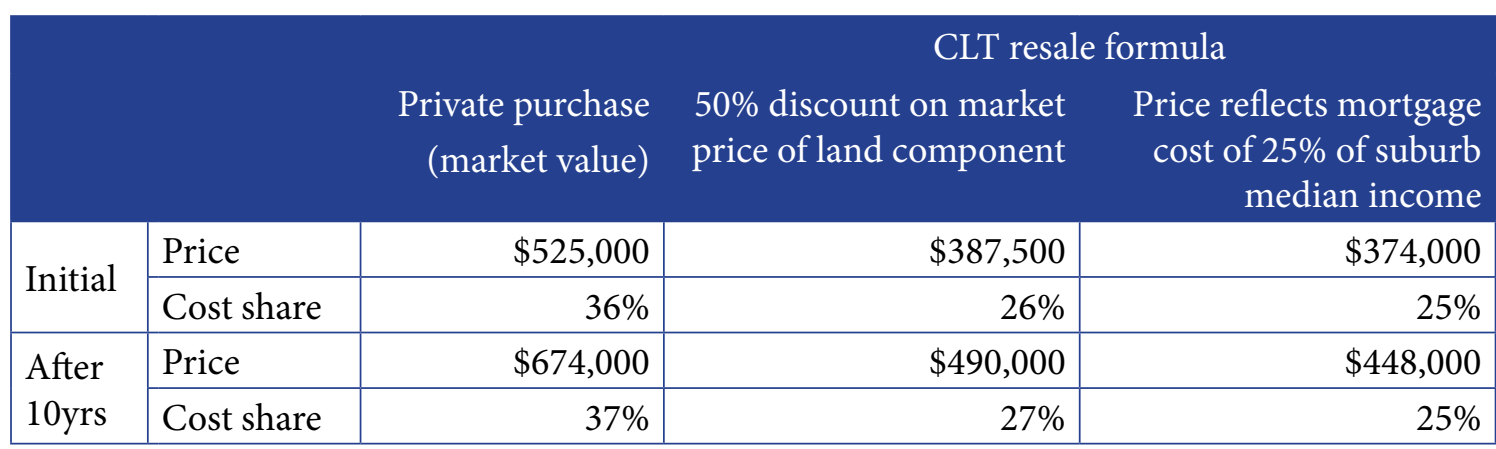

Scenario as in Table 6 , with $3 \%$ land price growth, $2 \%$ median income growth, interest rates at $5 \%, 2 \%$ increase dwelling replacement cost, and an initial median income at $\$ 85,000$. Cost share the repayment for an $80 \%$ loan-to-value mortgage over 25 years compared to median income.

44 "For example, if an owner buys a single-family home for $\$ 100,000$ that was appraised at $\$ 200,000$ (a 50 percent share of the property's value) and the home appreciates to $\$ 300,000$, the owner may sell the home for $\$ 100,000+[50 \% \times 25 \% \times(\$ 300,000-\$ 200,000)]=\$ 112,500$ "

Temkin, K. et. al. (2010). p3.

45 Crabtree, L. et. al. (2013). p17.

46 Ibid. 


\section{Core economic lever of CLTs}

To be clear, resale price formulas that reference the market price are actually referencing the market price of the same dwelling assuming that it is not part of the CLT. The fact that the land is within a CLT will change the willingness of buyers to pay for the dwelling, because of resale controls that reduce the financial value of ownership. In the example in Table 7, the value the homeowner can get upon sale in the CLT is far lower than in the private market. The property right of the CLT-resident should therefore be valued less than the property right of a private owner in the open market. Specifically, its value will be lower by the present value of the reduction in the expected price received upon a future sale. The CLT-market-value is actually lower than the private-market-value.

To demonstrate the effect of resale controls on the CLT-market-value for these two cases, Table 8 compares three important figures at the initial CLT sale:

1. The private-market-value, which is the value of the same land and dwelling - assuming it is not in a CLT and has all the property rights associated with standard property ownership.

2. The CLT-price, which is the regulated sale price based on the CLT resale formula.

3. The CLT-market-value, which is what a willing buyer would pay at an auction for the right to buy into the CLT and be subject to future resale price controls.

The private-market-value and CLT-price are from the initial sale in Table 7. The CLT-market-value accounts for resale price controls reducing the sale price by $\$ 168,000$ and $\$ 184,000$ after 10 years (again from the scenarios in Table 7). The present values of these lower future sale incomes are $\$ 111,000$ and $\$ 136,000$ today respectively, at a $5.2 \%$ discount rate. Therefore, the CLT-market-value, which is what the CLT property rights with the resale controls in place would sell for at auction today, would be $\$ 414,000$ and $\$ 389,000$ respectively.

\section{TABLE 8: EFFECT OF CLT RESALE CONTROLS ON MARKET VALUE OF DWELLING}

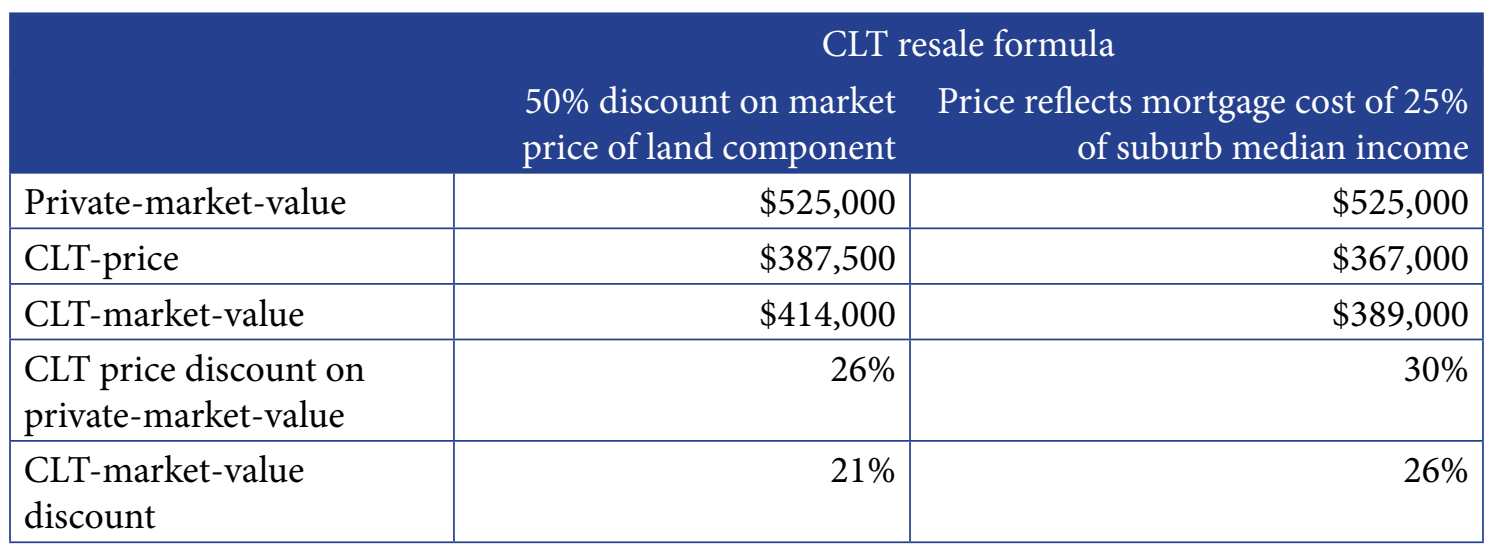

The last two rows show that while the resale price controls ensure that the price at which the property rights change hands are $26 \%$ and $30 \%$ below the current private-market-value, the controls on the next sale actually make these rights worth $21 \%$ and $26 \%$ below the private-market-value anyway. This means that although the secure housing offered in a CLT is cheaper to access, it is worth less in a financial sense because much of the capital gains or monopoly rents from traditional private homeownership are not part of the CLT property right. 


\section{Non-market rationing for CLT rights}

Although the resale price controls decrease the value of CLT ownership compared to private ownership, there is no guarantee that regulated prices are near this value. It may be the case that the regulated price is still far below the CLT-market-value.

Without being able to ration access to CLT ownership to the highest bidder (who would pay the CLTmarket-value) some form of queuing will occur.

Typically, CLTs first ensure the eligible buyers need housing support, with low incomes and few, or no, assets. Then, two basic methods are used to choose from this group of potential qualifying buyers:

1. Lottery - when a home becomes available in a CLT the buyer is chosen randomly from the list of qualifying applicants.

2. Waiting list - the person who first joined the list of qualifying applicants is the next to be able to purchase.

While the economics profession might view such systems are inferior to pricing, the main point of the CLT is to provide housing options that do not reflect the monopoly land price. Since no resale formula will be unable to ensure that the CLT-price and CLT-market-value are always close throughout the property cycle, a degree of non-market allocation is necessary, and even beneficial for those able to access housing through these non-market means.

An alternative way to deal with this problem is for the CLT to auction the rights when a CLT-owner sells, but pay the CLT-owner the regulated price, keeping the difference to use as a subsidy to expand the CLT.

\section{Limitations of CLTs}

The primary economic limitation of CLT ownership is that CLT owners do not get all the benefits from capital gains to land prices. This is intentional, and as discussed, reduces the value of homeownership in a CLT. However, what it means is that buyers with sufficient incomes who want to purchase both secure longterm housing and a financial investment in land will not find this option attractive.

CLT supporters would argue that this is a good thing, because it means that CLTs attract buyers who would otherwise be long term renters, increasing overall housing security and decreasing housing costs in the long-term.

While financing for CLT home construction, or related borrowings for new residents, have been noted to be a problem, ${ }^{47}$ many banks already offer lending for home construction in the ACT's land rent scheme. They could certainly offer a nearly identical loan for CLT residents.

Again, if state governments or even the federal government are committed to affordable housing options, they could even offer loans themselves for new CLT residents using their capacity to borrow cheaply in bond markets. This could further reduce the costs to CLT residents by ensuring they get a fair interest rate on any borrowing. 
$-$

SO, WHAT?

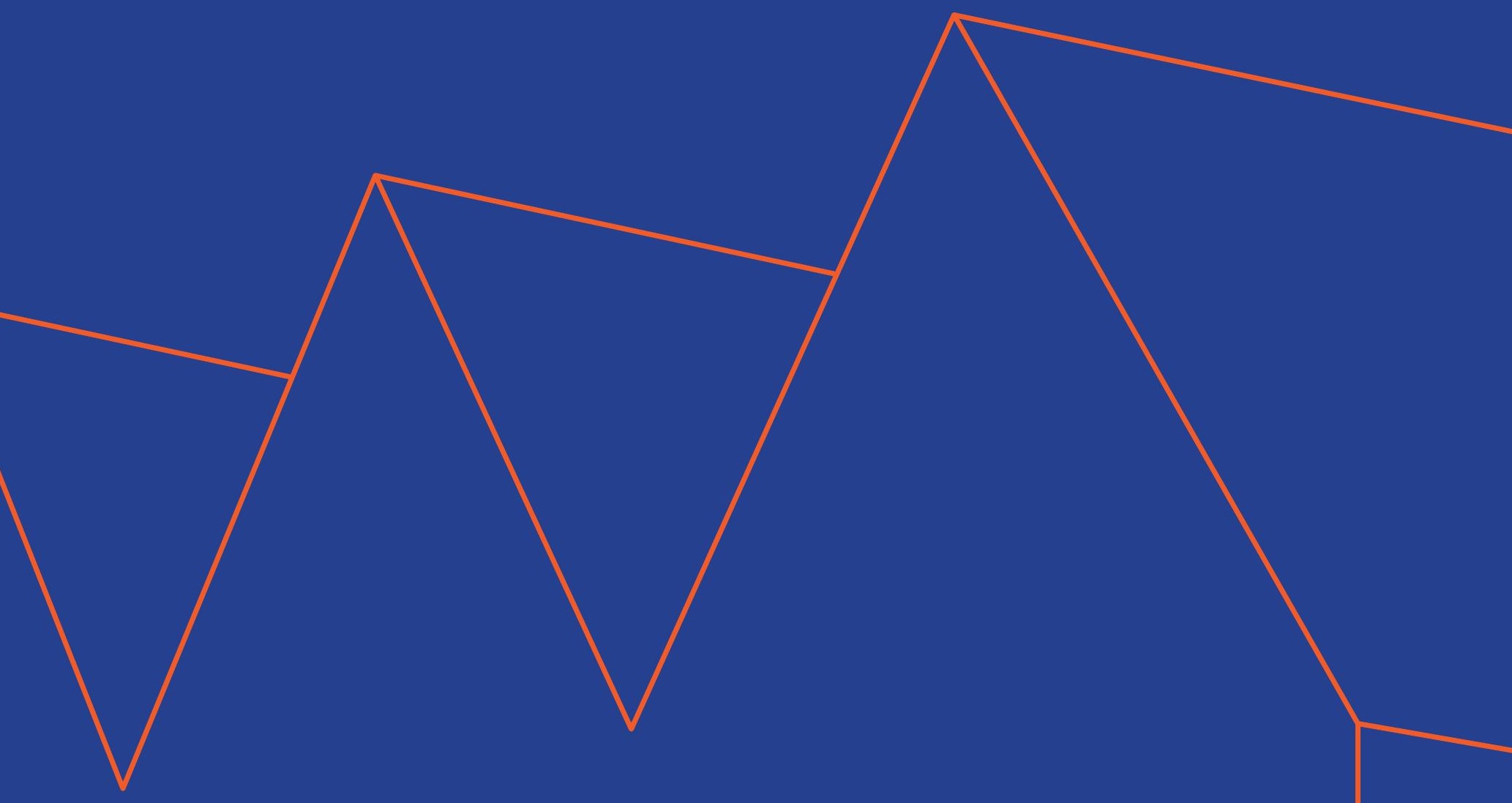


These two schemes - a publicly-run land rent scheme, and privately-run community land trust-are effective and proven alternatives for providing secure housing below the market price. While the residents in each scheme get the security benefits of homeownership, the compromise in both schemes is that residents do not get to keep all the capital gains from future increases in market prices. They don't pay the monopoly price for land, and they won't be able to receive it in the future either.

Many renters who desire homeownership for the security rather than as a financial investment will find that these schemes offer enormous net benefits, as high take-up by former renters in the ACTs LRS demonstrates. Both schemes offer a more secure long-term form of residency, insulated from changes in market prices, for less than the cost of renting at market prices.

In an environment of underfunded public housing, these housing models can act as a vital political circuit breaker on the need for housing alternatives. They strike an effective balance between the public interest and private incentives. In time, either scheme can be self-funding, reducing the reliance on government revenues. Yet neither option is currently part of the mainstream debate on how to make housing more affordable. These unspoken alternatives simply do not conform to the currently accepted economic idea that we should 'make markets work'. But because the land market, to which all housing is attached, is a monopoly, any policy to make housing cheaper should actively defy markets.

\section{How to get more housing without the land monopoly?}

Any government could start a Land Rent Scheme at any point if they wanted to create a housing alternative at below-market prices. At any time, any level of government could redirect their generous housing subsidies which currently go to landholders to new CLTs in the form of rezoning, conditions on larger land developments, or government-supported borrowing.

The main issue stopping the expansion of these types of housing options is the political will to subsidise housing in a way that reduces costs for residents. In the United States, the growth of CLTs has predominantly relied upon subsidies from local governments who have been pressured to respond to high housing prices, typically in the form of favourable rezoning, but also through philanthropic funding, such as from churches. 


\section{Policy ideas}

All levels of government have opportunities to create LRS schemes or subsidise CLTs if they desire to expand the housing options of residents to include cheaper alternatives. Should the political will exist, local governments could:

1. Adopt planning schemes that incorporate provisions for higher densities for CLTs only, allowing organisations intending to start CLTs to outbid other purchasers for sites, then develop at higher densities.

2. Create and fund a land development body that purchases land at market price and offers lots (or apartments) for sale under an LRS scheme. The body could be self-funding from land rents and land price gains.

Additionally, existing subsidies and schemes that go to landholders, like rezoning land without charging the value of these new development rights, or rates discounts, could be eliminated.

State governments could:

1. Offer state-owned land to CLT organisations conditional on supplying housing at below-market prices.

2. Create and fund a land development body that purchases land at market price and offers lots (or apartments) for sale under an LRS scheme. The body could be self-funding from land rents and land price gains.

Additionally, state-government housing subsidies that go to landholders can be removed, like FHOGs and stamp duty discounts, with the increased revenue used to facilitate more non-market-priced housing. The federal government could, in addition to the same options available to local and state governments, offer cash subsidies to community organisations to purchase land for CLTs. It could also remove tax concessions for landholders, like the 50\% capital gains tax discount, and other tax advantages like the ability to deduct losses from labour incomes for property investors (negative gearing).

These ideas are not radical. Governments already subsidise landholders to the tune of billions of dollars per year, and the ACT already has a Land Rent Scheme in place. The only radical thing about these housing options is that they don't conform to the narrow conditions of the Australian housing debate that insists market-priced home access is the only option. 



\section{TheAustralialnstitute}

Research that matters.

$\underset{\text { australia }>}{\text { aus }}$

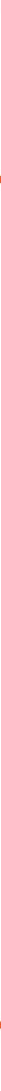

